\title{
JUURNAL.RU
}

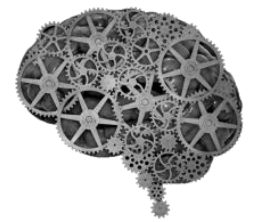

COMPANY GROUP "INTELLEKT"

\author{
Тучина Н.А \\ Саратовский социально-экономический институт РЭУ им. Г.В. Плеханова \\ Саратов, Россия
}

doi: 10.18411/lj2016-6-4-09

\section{Актуальность исследования естественных монополий в российских условиях}

Естественные монополии в экономике России имеют большой удельный вес и составляют основу внутреннего валового продукта России, где занимают долю порядка 80-85\%. Естественные монополии России рассматриваются как состояние товарного рынка, при котором удовлетворение спроса на этом рынке эффективнее в отсутствие конкуренции, в силу технологических особенностей производства, а товары, производимые субъектами естественной монополии, не могут быть заменены в потреблении другими товарами. Спрос на данном товарном рынке в меньшей степени зависит от изменения цены на этот товар, чем спрос на другие виды товаров.

В настоящее время, в условиях разразившегося кризиса, естественные монополии заслуживают особо пристального внимания, так как являются базой устойчивого развития отечественной экономической системы.

В данной статье уделим особое внимание ОАО «РЖД», как примеру монополии в России. Ни для кого не секрет, что РЖД является единственным продавцом на рынке железнодорожных перевозок. Хотя РЖД и имеет сложную структуру, в которую входят многочисленные филиалы, дочерние и зависимые компании, она является фундаментом компании.

Деятельность компании на сегодняшний день, несмотря на происходящие трансформации [1, с. 141-145], является привлекательной и стоит отметить ее 
развитость и совершенствование. Транспортная система, а именно РЖД не единственный способ перевозок, многие отдают предпочтение и авиаперевозкам и автоперевозкам, но статистика показывает, что спрос на услуги РЖД не снижается. Услуги РЖД как монополиста, уникальны, но есть и недостаток данных услуг, а именно цены, которые устанавливает непосредственно руководство ОАО РЖД. Другими словами, компания выступает в качестве прайс-мэйкера, где самостоятельно формирует предложение на рынке услуг железно-дорожного транспорта.

Но полагаем, что изменения в деятельности данной отрасли, воздействуют на все макроэкономические показатели.

Установленные естественными монополиями тарифы влияют на рост или падение такого важного показателя страны как экономическое благосостояние общества и индекс промышленного производства. Снижение индекса производительности в данной сфере может затянуть экономику в ещё более глубокий кризис.

С 2014 года, в связи с экономическим кризисом и введением антироссийских санкций, российская экономика вступила в промышленную рецессию, сопровождающуюся обесценением рубля, снижением цен на нефть, ростом безработицы и приостановкой инвестиционных программ.

Можно проследить ситуацию изменения тарифов на железнодорожные перевозки в 2014-2015 годах в России. Во второй половине 2014 года предстоящая индексация тарифов привела к целой серии митингов профсоюзов по всей стране. Из-за кризиса в угольной отрасли цены на мировых рынках угля упали более чем в 2 раза. Более $70 \%$ угольных предприятий оказались убыточны. Учитывая, что транспортные расходы в цене угля составляют 60\% и более, увеличение тарифов, могло бы привести к дальнейшему сокращению инвестиций, вложений в охрану труда, снижению социальных гарантий, а также спровоцировать закрытие угольных предприятий. При повышении тарифов на 
перевозки и сохранении действующих цен на уголь его попросту было бы невыгодно добывать.

Ситуация усугубляется ещё и тем, что США и страны Евросоюза ввели санкции в отношении России, и российский уголь не принимают в Польше и Украине.

Рост тарифов в данной ситуации привёл бы к тому, что компании вынуждены, будут сокращать грузоперевозки, что нанесёт удар по экономическим показателям самих железнодорожников, а четыре десятка предприятий по всей России попросту обанкротятся.

В декабре 2014 г. на сайте Федеральной службы по тарифам был опубликован пресс-релиз, в котором было сказано, что в соответствии с прогнозом социально-экономического развития России на 2015 год и плановый период 2016 и 2017 годов и по итогам заседания Правительства Российской Федерации 27 ноября 2014 года, на котором были рассмотрены финансовый план и инвестиционная программа ОАО «РЖД», рост тарифов на грузовые железнодорожные перевозки составит: в 2016 году - 5,5\%; в 2017 году - 4,5\% [2].

Власти увеличивают тарифы на услуги естественных монополий, это провоцирует рост инфляции, рост инфляции даёт большие издержки для монополий, что опять-таки приводит к необходимости увеличивать тарифы на услуги монополий. В итоге повышение уровня тарифов естественных монополий вслед за ростом инфляции приведёт к ещё большему росту цен в целом и раскручиванию инфляционной спирали. В условиях, когда по различным оценкам вклад роста тарифов в инфляцию составляет от $30 \%$ и выше, повышение тарифов приведёт к существенному разгону роста цен.

Проблема, связанная с повышение тарифов, имеет двоякий характер. С одной стороны, в краткосрочном периоде повышение тарифов естественных монополий оказывает негативное влияние на все хозяйствующие субъекты, которые формируют сильные коалиции по противодействию повышению тарифов. С другой стороны, недоинвестирование в развитие естественных 
монополий может привести к появлению ограничений для экономического роста в долгосрочном периоде [3].

Считаем, что государственное регулирование тарифов для субъектов естественных монополий по РФ в условиях реформирования должно быть направлено на реализацию комплекса мер по сдерживанию цен (тарифов) естественных монополий с целью создания условий для развития полноценной конкуренции в сферах, сопряжённых со сферами естественных монополий.

Правительство должно проводить активную антисанкционную политику с помощью институциональных преобразований, чтобы не усугубить еще больше положение естественных монополий в условиях кризиса и, в тоже время, не дать им переложить все издержки на потребителя.

Рациональное регулирование отраслей естественных монополий является ключевой задачей, стоящей перед государством, потому, что именно они в огромной степени определяют структуру производственных и потребительских цен. Речь идёт о тарифах, которые устанавливают естественные монополии на свои товары и услуги. 


\section{Литература:}

1. Ежова В.О., Устинова Н.Г. Стратегии развития предприятий в условиях кризиса: институциональный подход. В книге: Wykształcenie i nauka bez granic - 2015. Materiały XI Międzynarodowej naukowi-praktycznej konferencji. 2015. C. 141-145.

2. Пресс-релиз по результатам Правления ФСТ России от 05.12.2014 «Об индексации тарифов на грузовые железнодорожные перевозки» [Электронный ресурс]/ Режим доступа: http://www.fstrf.ru/press/news/1906

3. Тучина Н.А. Возможности и перспективы инновационного развития России в глобализирующемся мире. //Наука и общество. 2012. № 6. С. 198-204. 